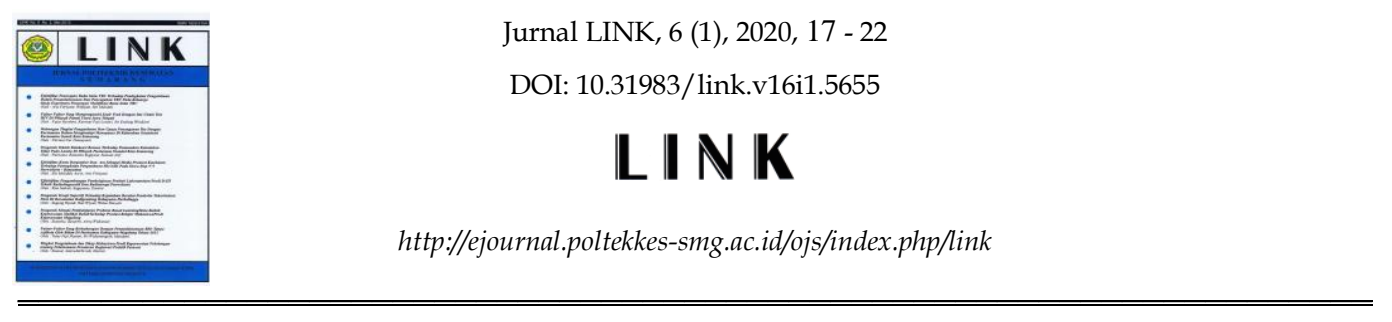

\title{
MODEL IMPLEMENTASI PEMBERIAN TABLET TAMBAH DARAH DI SEKOLAH MENENGAH
}

\author{
Anita Widiastutia*, Ulfah Musdalifah ${ }^{\mathrm{b}}$, Fitria Zuhriyatun ${ }^{\mathrm{c}}$ \\ $a, b, c$ Jurusan Kebidanan ; Poltekkes Kemenkes Semarang \\ Jl. Tirto Agung ; Pedalangan; Banyumanik; Semarang
}

\begin{abstract}
Abstrak
Kementerian kesehatan menyelenggarakan program pemberian tablet tambah darah untuk remaja putri. Ini merupakan program baru dari pemerintah. Tablet dibagikan gratis untuk remaja putri usia sekolah menengan melalui Puskesmas. Tujuan penelitian ini adalah untuk mengetahui model yang efektif dalam implementasi program pemberian tablet tambah darah pada remaja putri di kabupaten Banyumas. Metode penelitian yang digunakan adalah deskriptif kualitatif. Data diperoleh melalui wawancara mendalam. Informan adalah pelaksana gizi di puskesmas, guru UKS pelaksana program di sekolah, dan siswi. Diperoleh tiga model atau pola dalam implementasi pemberian tablet tambah darah pada penelitian ini. Permodel yang lebih efektif dalam pemberian TTD dengan adanya pemberdayaan petugas puskesmas terhadap guru sekolah dan perwakilan siswi dalam mengelola ditribusi dan konsumsi tablet tambah darah. Untuk meningkatkan kepatuhan remaja putri dalam mengkonsumsi tablet tambah darah, diperlukan peningkatan pemberdayaan pihak guru dan siswi oleh pelaksana gizi puskesmas supaya tujuan program pemberian tablet tambah darah untuk remaja putri bisa efektif.
\end{abstract}

Kata Kunci:, anemia, remaja putri, tablet tambah darah, model implementasi

\begin{abstract}
[MODEL OF IMPLEMENTATION FE SUPPLEMENTATION TABLETS IN THE HIGH SCHOOL] The Ministry of Health is release a program for giving Fe supplementation tablets to adolecencts. This is a new program from the government. Tablets are distributed free of charge for adolecencts through primary health care. The purpose of this study was to determine an effective model in the implementation of the program of adding Fe supplementation tablets to adolescent in Banyumas district. The research method used is descriptive qualitative. Data obtained through in-depth interviews. The informants were nutrition implementers at the primary health care, teachers implementing the programs at schools, and students. Three models or patterns were obtained in the implementation of giving Fe supplementation tablets in this study. Three models or patterns were obtained in the implementation of giving blood added tablets in this study. A more effective permodel in giving (blood-added tablets) TTD is by empowering puskesmas staff for school teachers and female representatives in managing the distribution and consumption of blood-added tablets. To improve adolecencts adherence in consuming Fe supplementation tablets, it is necessary to increase the empowerment of teachers and students by primary health care nutrition practitioners so that the goal of giving Fe supplementation tablets to adolecencts can be effective.
\end{abstract}

\section{Keywords: anemia, adolecencts, Fe supplementation, implementation model}

\section{Pendahuluan}

Dewasa ini anemia pada remaja menjadi salah satu masalah kesehatan masyarakat, karena prevalensinya masih cukup tinggi. Remaja yang kekurangan besi menimbulkan

*) Correspondence Author (Anita Widiastuti)

E-mail: anitawidiastuti123@gmail.com banyak permasalahan kesehatan. Risiko masalah kesehatan jangka panjang lebih besar apabila yang mengalami anemia adalah remaja putri (rematri). Hal ini berkaitan dengan siklus hidup manusia. Pada awal kehidupan, manusia berada pada rahim wanita, jika wanita yang sedang hamil kondisinya baik maka akan lahir 
generasi yang baik. Namun apabila kondisi wanita pada saat meneruskan generasinya dalam kondisi buruk, maka akan lahir generasi yang kualitasnya buruk. Untuk itu sebagai persiapan jangka panjang wanita mulai dari remaja harus selalu dalam kondisi yang baik, termasuk gizinya.

Kejadian anemia di Indonesia berdasarkan data Riskesdas 2013 masih didominasi oleh perempuan. Sedangkan dilihat dari kelompok umur, maka kelompok umur remaja dan kelompok umur lansia memiliki prosentase yang cukup tinggi. Usia remaja menduduki peringkat nomer dua terbanyak(Balitbang Kemenkes RI, 2013).

WHO menyampaikan rekomendasi pada World Health Assembly (WHA) ke-65 yang menyepakati rencana aksi dan target global untuk gizi ibu, bayi, dan anak, dengan komitmen mengurangi separuh (50\%) prevalensi anemia pada WUS pada tahun 2025. Pemerintah Indonesia responsive terhadap rekomendasi WHO tersebut dengan melakukan intensifikasi pencegahan dan penanggulangan anemia pada rematri. Upaya dilakukan dengan memprioritaskan pemberian TTD melalui institusi sekolah(WHO, 2016).

Untuk menguatkan program tersebut diterbitkan Permenkes nomor 88 tahun 2014 tentang standar tablet tambah darah bagi wanita usia subur dan ibu hamil. Selanjutnya ditindaklanjuti dengan surat edaran Dirjen Kesmas Nomor HK.03.03/V/0595/2016 tentang pemberian tablet tambah darah pada remaja putri dan wanita usia subur(Dirjen Kesmas Kementerian Kesehatan, 2016).

Strategi pencegahan dan penanggulangan anemia salah satunya dilakukan dengan suplementasi tablet tambah darah (TTD) pada remaja putri, yang kegiatan ini merupakan kebijakan nasional. Keseriusan pemerintah dalam hal ini di kuatkan dengan penerbitan Permenkes RI.

Data riskesdas tahun 2018 menunjuukan bahwa 70\% remaja putri usia 10-19 tahun sudah mengalami menstruasi. $80 \%$ remaja memperoleh TTD di sekolah, 11 memperoleh dari faskes kan hanya $9 \%$ yang inisiatis membeli sendiri(Balitbang Kemenkes RI, 2018).

Upaya Dinas Kesehatan Kabupaten Banyumas yaitu melaksanakan kegiatan pencegahan dan penanggulangan anemia pada rematri diawali dengan sosialisasi pemberian tablet tambah darah. Tindakan program pencegahan dan penanggulangan anemia sudah dilakukan dengan droping tablet tambah darah. Berdasarkan informasi dari petugas kesehatan didapatkan informasi bahwa program pemberian tablet $\mathrm{Fe}$ sudah dijalankan oleh bagian gizi Puskesmas.

Mengamati permasalahan yang ada pada rematri tersebut perlu dilakukan penelitian model implementasi pemberian pemberian tablet tambah darah pada remaja putri di wilayah Kabupaten Banyumas untuk mendapatkan model yang paling efektif.

Penelitian terkait program tablet tambah darah pada remaja putri di sekolah pernah dilakukan oleh Nuradhiani (2018) bahwa guru berpengaruh terhadap kepatuhan remaja putri dalam konsumsi tablet tambah darah, namun dalam penelitian tersebut belum dijelaskan bagaimana model pelaksanaan program tersebut di sekolah-sekolah (Nuradhiani et al., 2017).

\section{Metode}

Metode penelitian adalah deskriptif kualitatif dengan jenis penelitian fenomenologi. Penelitian ini menggali data untuk menemukan penjelasan dari hal-hal mendasar dan esensial dari fenomena, realitas, atau pengalaman yang dialami oleh objek penelitian

Informan dalam penelitian ini adalah pelaksana program gizi puskesmas, guru UKS/ pengelola program tablet tambah darah di sekolah, dan siswi/remaja putri yang menjadi sasaran program pemberian tablet FE. Puskesmas dan sekolah diwakili dari wilayah kota administratif, wilayah kabupaten dan sekolah swasta.

Data diperoleh dengan wawancara mendalam menggunakan pedoman wawancara dan alat perekam suara. Uji Validitas dalam penelitian ini menggunakan triangulasi sumber, untuk membandingkan hasil temuan pada informan utama dengan informan triangulasi.

\section{Hasil dan Pembahasan}

Penelitian tentang implementasi program tablet tambah darah pada remaja putri dilaksanakan pada SMP Negeri di wilayah kota, SMP Negeri diwilayah kabupaten dan SMP swasta.

Hasil penelitian, menunjukkan program pemberian tablet tambah darah sudah dilaksanakan di sekolah sekolah sesuai program pemerintah. Ada tiga model yang dapat 
digambarkan. Di semua model pelaksanaan program pemberian tablet tambah darah, pihak puskesmas sudah mengawali dengan survey jumlah siswi ke sekolah yang menjadi sasaran. Untuk selanjutnya puskesmas melakukan droping obat ke sekolah sekolah(Direktorat Gizi Masyarakat Dirjen Kesmas, 2016).

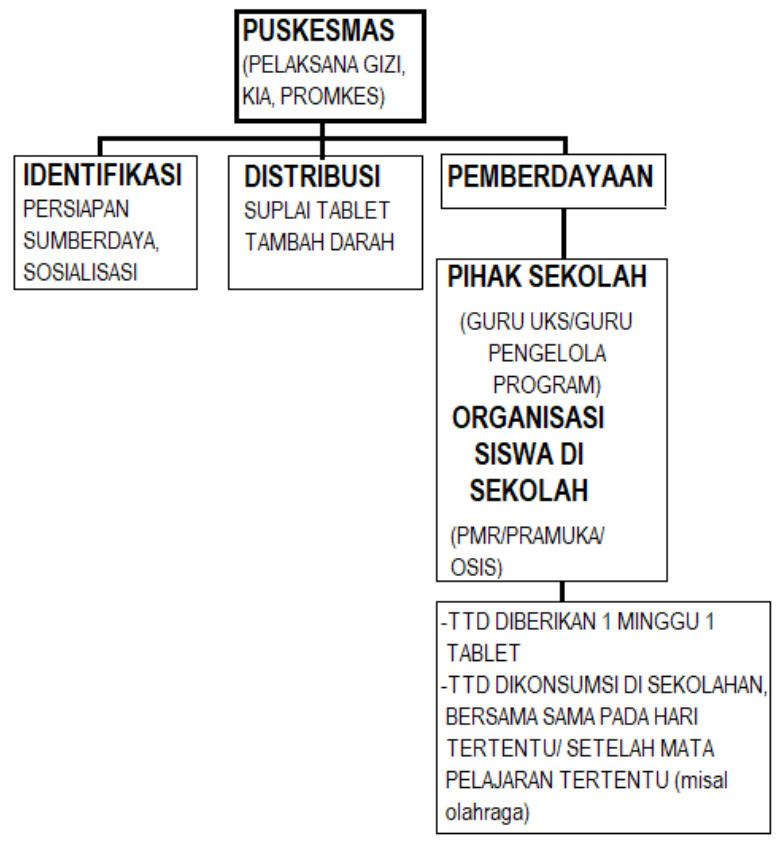

Gambar 1 Model pemberian tablet tambah darah 1

Setiap model memiliki tingkat keberhasilan yang berbeda beda. Semakin tinggi tingkat pemberdayaan yang dilaksanakan, keberhasilan program semakin baik. Keberhasilan dilihat berdasarkan laporan tingkat kepatuhan siswi yang menjadi sampel dalam mengkonsumsi TTD. Kepatuhan menjadi komponen penting dalam keberhasilan program pemberian tablet tambah darah. Seperti di sampaikan oleh Yuniarti (2015) dalam penelitiannya menyampaikan bahwa terdapat hubungan yang signifikan antara kepatuhan konsumsi tablet tambah darah pada remaja putri dengan kadar hemoglobin(Yuniarti et al., 2015).

Penelitian Yuniarti merupakan cermin dari kebiasaan remaja putri. Ada remaja yang patuh da nada pula sekelompok remaja yang kurang patuh. Untu itu perlu model implementasi yang bisa meminimalkan ketidakpatuhan remaja putri. Karena dengan kepatuhan konsumsi tablet keberhasilan pencegahan anemia pada remaja bisa terlaksana.

Model-model pemberian tablet tambah darah pada remaja putri disajikan dengan gambar dan penjelasan tingkat keberhasilan program di tingkat sekolah.

Pada model 1, diperlihatkan dengan gambar 1, pihak puskesmas menggandeng pihak sekolah untuk terlibat pada program ini. Keterlibatan dilakukan dengan pemberdayaan guru UKS/olah raga di sekolah, untuk mengelola stok persediaan TTD. Selanjutnya TTD tersebut diberikan ke siswi 1 minggu 1 tablet dan dikonsumsi di sekolahan secara bersama sama.

Hasil wawancara dengan pengelola program gizi puskesmas, pihaknya telah mendistribusikan tablet tambah darah ke sekolah. Hal ini dibenarkan oleh pihak sekolah. Tablet disimpan dan dikelola oleh guru UKS. Setiap minggu guru mendistribusikan tablet ke perwakilan siswi, untuk selanjutnya diminum bersama sama dengan teman sekelas. Guru mengaku aktif mengevaluasi konsumsi tablet, dan menurutnya tablet dikonsumsi sesuai petunjuk puskesmas. Menurut pengakuan siswi, obat yang diberikan selalu diminum, karena tablet harus diminum di sekolahan.

Penelitian oleh Sanderi (2013) menjelaskan bahwa siswa akan lebih patuh dalam menjalankan kedisiplinan di sekolah. Hal ini disebabkan adanya upaya guru yang lebih, sehingga informasi yang didapat siswa menjadi lebih baik. Kondisi ini hampir sama dengan pelaksanaan konsumsi tablet tambah darah yang menganjurkan minum tablet di sekolah, hasilnya siswi disiplin dengan ketentuan yang diterapkan di sekolah(Sanderi et al., 2013).

Guru dapat pula melakukan pemberdayaan dengan melakukan piket pada siswi yang ikut organisasi di sekolah. Tekniknya dengan ditugasi mengambil TTD yang disimpan oleh guru setiap minggunya, selanjutnya perwakilan siswi tersebut membagikan ke teman temannya, dan dikonsumsi di sekolah secara bersama-sama

Menurut Amir (2019) berdasarkan hasil review dari beberapa penelitian dapat disimpulkan bahwa faktor-faktor yang berhubungan dengan konsumsi TTD pada remaja putri di Indonesia yaitu dukungan guru $(\mathrm{OR}=4,7)$, sikap $(\mathrm{OR}=2,192)$, budaya $(\mathrm{OR}=2,517)$, juga dukungan keluarga. Faktor yang tidak kalah penting adalah perceived threat (ancaman yang dirasakan). Hasil review tersebut menunjukkan bahwa guru berperan 4,7 kali dalam keberhasilan program tablet tambah darah pada remaja putri(Amir \& Djokosujono, 2019). 
Pelaksanaan pemberian tablet tambah darah ada model yang berbeda. Pada model kedua ditampilkan pada gambar 2, pelaksanaan program tidak berbeda jauh dengan model 1 .

Hasil wawancara dengan pengelola program puskesmas pihaknya telah bekerjasama dengan pihak sekolah dalam pengelolaan tablet tambah darah. Dipihak sekolah tablet disimpan untuk selanjutnya di ambil oleh siswi setiap minggunya. Menurut guru pengelola pihaknya hanya mengkoordinir pembagiantablet dan memotivasi untuk diminum. Pengakuan siswi yang diwawancara ada yang patuh dengan minum tablet di sekolah, tetapi ada pula yang membawa pulang tablet tersebut. Tablet yang di bawa pulang, kadang di minum dan kadang tidak diminum.

Pada model 2 ada pemberdayaan guru di sekolah, yang mengelola TTD untuk diberikan ke siswi 1 minggu 1 tablet. Perbedaan terletak pada tidak ada ketentuan TTD diminum di sekolah. Sehingga memungkinkan TTD ada yang di bawa pulang. Berdasarkan laporan dari siswi, TTD yang di bawa pulang kadang-kadang tidak diminum. Kondisi ini kurang mendukung dari tujuan program.

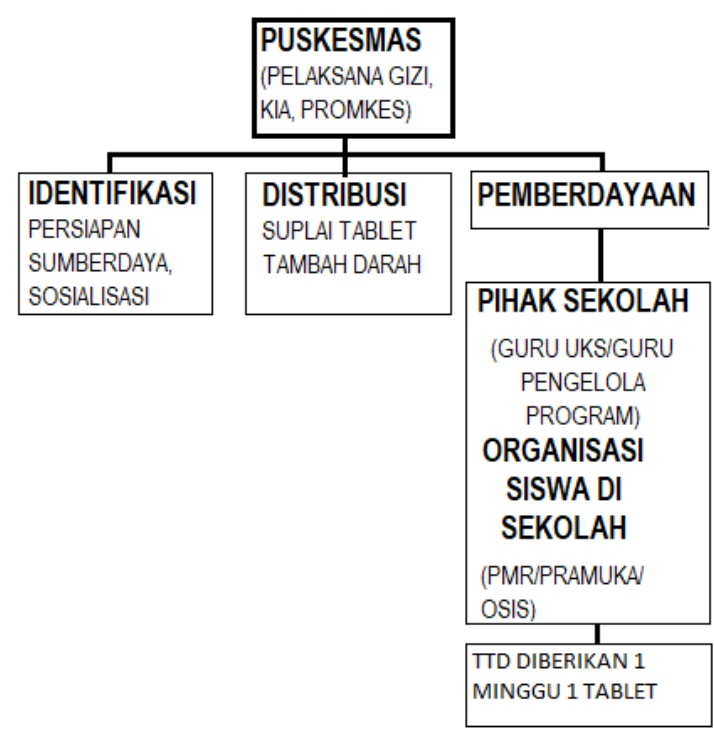

Gambar 2 Model pemberian tablet tambah darah 2

Model kedua ini sudah ada pemberdayaan, hanya saja pengawasan masih lemah sehinyya pencapaian program menjadi kurang baik. Model ini seperti penelitian yang dilakukan oleh Anggraeni (2018). Pada hasil penelitiannya menyimpulkan bahwa meskipun program tablet tambah darah sudah dikelola oleh guru, tetapi apabila kurang pengawasan dalam mengkonsumsi tablet maka program pencegahan dan penanggulangan anemia remaja pencapaiannya menjadi kurang(Villa Anggreini et al., 2018).

Berdasarkan gambaran pelaksanaan dan laporan kepatuhan, pada model 2 kepatuhan siswi dalam konsumsi TTD kurang baik. Sehingga model ini kurang baik untuk dilaksanakan.

Untuk model pemberian tamblet tambah darah ketiga, pelaksanaan seperti gambar 3 . Dalam pelaksanaannya puskesmas bergerak sendiri. Tidak ada pemberdayaan guru maupun siswi di sekolah. Tablet langsung diberikan ke siswi oleh pihak puskesmas. Tablet diberikan untuk periode lebih dari satu bulan. Dan tidak ada pengawasan baik dari pihak puskesmas maupun sekolah dalam kepatuhan konsumsi tablet. Pihak sekolah kurang peduli karena tidak ada koordinasi dari puskesmas.

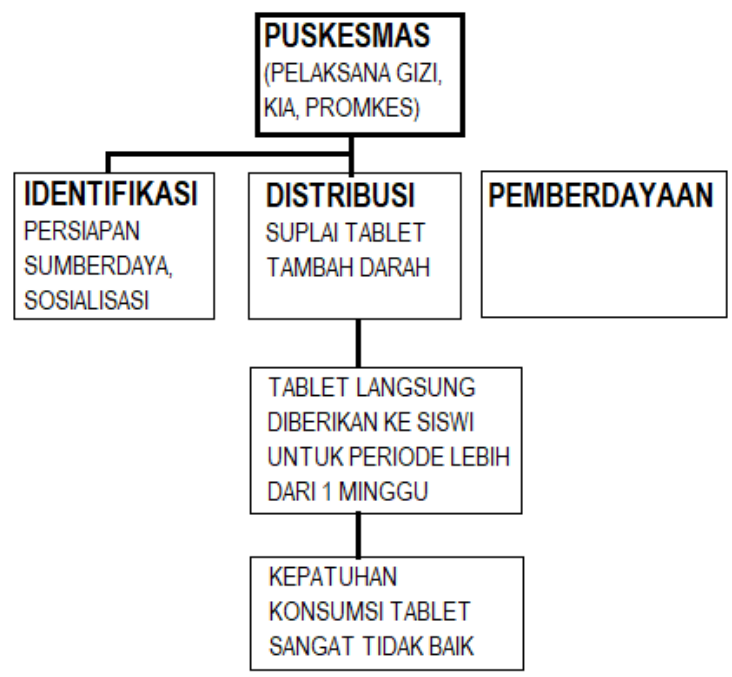

Gambar 3 Model pemberian tablet tambah darah 3

Temuan selanjutnya diperoleh berdasarkan informasi dari pihak puskesmas yang telah mengumpulkan siswa untuk sosialisasi tablet tambah darah. Selain sosialisasi juga membagikan sejumlah tablet ke siswi untuk jangka waktu tertentu. Kondisi ini membuat pihak sekolah tidak bisa memantau kepatuhan siswi. Menurut guru pengelola pihaknya hanya mengingatkan siswi untuk mengkonsumsi tablet, namun demikian siswi juga melapor kepada guru bahwa siswi tidak minum dengan alasan lupa dan malas. Setelah dilakukan pengecekan ternyata sama dengan laporan 
pihak guru. Siswi hanya minum tablet satu kali bersamaan dengan kegiatan sosialisasi.

Kepatuhan siswi dalam mengkonsumsi tablet tabah darah sangat dipengaruhi oleh faktor lingkungan. Seperti dijelaskan dalam penelitian Risva. Pada kondisi dimana teman teman patuh minum tablet tambah darah, akan mempengaruhi teman yang lain untuk patuh. Demikian pula sebaliknya, bila lingkungan tidak mendukung maka remaja menjadi tidak patuh (Risva \& Rahfiludin, 2016)

Laporan, dari siswi yang menjadi informan sebagian besar tablet dibawa pulang. Ketika tablet sudah di bawa pulang koordinasi dan pemantauan oleh pihak sekolah menjadi kurang efektif. Akibatnya tujuan program menjadi tidak efektif.

Ada faktor lain yang bisa meningkatkan efektifitas program ini. Yaitu niat dari remaja putrid. Seperti penelitian Syima, yang menjelaskan hubungan antara niat dengan kepatuhan konsumsi tablet tambah darah pada remaja puti (Syaima et al., 2017)

Puskesmas yang menerapkan model 3 ini sangat tidak di rekomendasikan. Hasil wawancara menunjukkan bahwa kepatuhan siswi dalam konsumsi TTD sangat tidak baik.

Model implementasi pada gambar 3 sering terjadi pada puskesmas yang kurang menerapkan aspek pemberdayaan seperti halnya disposisi dalam pelaksanaan program. Pada penelitian Mutmainah (2017) tentang keberhasilan cakupan tablet tambah darah pada ibu hamil, puskesmas yang menerapkan disposisi memiliki cakupan yang baik Pada puskesmas yang tidak menerapkan disposisi menganggap kurang pentingnya disposisi dalam keberhasilan program. Terbukti dengan cakupan yang rendah merasa sudah berjalan baik dan menyampaikan tidak ada permasalahan(Triana Mutmainah et al., 2014).

\section{Simpulan dan Saran}

Berdasarkan hasil penelitian tentang Model Implementasi Pemberian TTD rematri dapat disimpulkan pihak Puskesmas perlu melakukan pemberdayaan dalam pelaksanaan program di tingkat sekolahan dengan dan harus ada kesepakatan pelaksanaan minum table di sekolah, karena bila tablet di bawa pulang kepatuhan konsumsi tablet sangat rendah. Sehinnga perlu peningkatan pemberdayaan pihak guru dan siswi oleh pelaksana gizi puskesmas supaya pemanfaatan tablet tambah darah oleh remaja putri lebih maksimal.

\section{Ucapan Terima Kasih}

Terimakasih banyak kami ucapkan pada Poltekkes Kemenkes Semarang untuk kesempatannya, penulis mendapatkan fasilitas untuk menyelesaikan penelitian. Ucapan terimakasih disampaikan kepada Pihak Puskesmas, dan sekolah serta semua pihak yang ikut berpartisipasi dalam penelitian ini.

\section{Daftar Pustaka}

Amir, N., \& Djokosujono, K. (2019). Faktor-Faktor yang Berhubungan dengan Konsumsi Tablet Tambah Darah (TTD) pada Remaja Putri di Indonesia: Literatur Review. Jurnal Kedokteran Dan Kesehatan, 15(2),

https://jurnal.umj.ac.id/index.php/JKK

Balitbang Kemenkes RI. (2013). Riset Kesehatan Dasar; RISKESDAS.

Balitbang Kemenkes RI. (2018). Riset Kesehatan Dasar; RISKESDAS.

Direktorat Gizi Masyarakat Dirjen Kesmas. (2016).

Buku-Pedoman-Pencegahan-Anemia-Rematri-d an-WUS (D. K. Direktorat Gizi Masyarakat (ed.)). Direktorat Gizi Masyarakat.

Dirjen Kesmas Kementerian Kesehatan. (2016). Pemberian tablet tambah darah pada remaja putri dan wanita usia subur. Kementerian Kesehatan RI.

Nuradhiani, A., Briawan, D., \& Dwiriani, C. M. (2017). Dukungan guru meningkatkan kepatuhan konsumsi tablet tambah darah pada remaja putri di Kota Bogor. Jurnal Gizi Dan Pangan, 12(3), 153-160. https://doi.org/10.25182/jgp.2017.12.3.153 $-160$

Risva, T. C., \& Rahfiludin, M. Z. (2016). Faktor-faktor yang Berhubungan Dengan Sebagai Upaya Pencegahan Anemia Pada Remaja Puteri (studi Pada Mahasiswa Tahun Pertama Di Fakultas Kesehatan Masyaratak Universitas Diponegoro). Jurnal kesehatan masyarakat, 4(April), 243-250.

Sanderi, F., Marjohan, \& Sukmawati, I. (2013). Kepatuhan Siswa Terhadap Disiplin dan Upaya Guru BK dalam Meningkatkannya Melalui Layanan Informasi. Konselor | Jurnal Ilmiah Konseling, 2(3), 220-224.

Syaima, N., Savitry, D., Arifin, S., Studi, P., Dokter, P., Kedokteran, F., Lambung, U., Ilmu, D., Masyarakat, K., Kedokteran, F., Lambung, U., Fisiologi, D., Kedokteran, F., 
Lambung, U., \& Banjarmasin, M. (2017). Hubungan dukungan keluarga dengan niat konsumsi tablet tambah darah pada remaja puteri. Berkala Kedokteran, 13(1), 113-118.

Triana Mutmainah, V., Achadi Nugraheni, S., \& Suparwati, A. (2014). Analisis Perbedaan Implementasi Program Suplementasi Tablet Besi Ibu Hamil oleh Petugas Gizi antara Puskesmas Cakupan Tinggi dan Rendah di Wilayah Kabupaten Kendal Manajemen Kesehatan Indonesia, 02(02), 140.

Villa Anggreini, T., Setyaningrum, R., Fakhriadi, R., \& Rosadi, D. (2018). Evaluasi Program Pencegahan Dan Penanggulangan Anemia Remaja Puteri Di SMPN 4 wilayah
Banjarbaru.

WHO. (2016). Who Guideline 1 : Daily Iron Supplementation In Adult Women And Adolescent Girls Executive Summary Available evidence.

https://www.who.int/nutrition/publicati ons/micronutrients/guidelines/summary daily_iron_supp_womenandgirls.pdf?ua $=1$

Yuniarti, Y., Rusmilawaty, R., \& Tunggal, T. (2015). Hubungan Antara Kepatuhan Minum Tablet Fe Dengan Kejadian Anemia Pada Remaja Putri di MA Darul Imad Kecamatan Tatah Makmur Kabupaten Banjar. Jurnal Publikasi Kesehatan Masyarakat Indonesia (Vol. 2, Issue 1). 